\title{
MEKANISME IMPEACHMENT DI NEGARA DENGAN SISTEM PRESIDENSIAL: STUDI PERBANDINGAN MEKANISME IMPEACHMENT DI INDONESIA DAN KOREA SELATAN*
}

\author{
Ryan Muthiara Wasti** \\ Hukum Tata Negara, Fakultas Hukum Universitas Indonesia \\ Jalan Prof. Mr. Djokosoetono, Kampus Universitas Indonesia, Depok 16424
}

\begin{abstract}
In the development of the government sistem, there are semi-presidential systems which are different from presidential and parliamentary systems. The difference is in the case of the presence of the President and Prime Minister as a parliamentary sistem but the mechanism for dismissing the President resembles the impeachment in the presidential systems. This research was conducted to see how the impeachment mechanism compares in countries with presidential sistems, especially Indonesia and in countries with a semi-presidential sistem, namely South Korea. The author finds that there are differences between the impeachment mechanisms in Indonesia and South Korea in the process and reasons for the termination of the President. This can be an input for the mechanism in Indonesia to focus more on legal mechanisms without a political mechanism in the MPR.
\end{abstract}

Keywords: semi-presidential systems, impeachment.

\section{Intisari}

Dalam perkembangan sistem pemerintahan, terdapat sistem semi presidensial yang berbeda dari sistem presidensial dan parlementer. Perbedannya adalah dalam hal adanya Presiden dan Perdana Menteri layaknya sistem parlementer tetapi mekanisme pemberhentian Presidennya menyerupai impeachment dalam sistem presidensial. Penelitian ini dilakukan untuk melihat perbandingan mekanisme impeachment di negara dengan sistem presidensial khususnya Indonesia dan di negara dengan sistem semi presidensial yaitu Korea Selatan. Penulis menemukan bahwa terdapat perbedaan antara mekanisme impeachment di Indonesia dan Korea Selatan dalam mekanisme maupun alasan pemberhentian Presiden. Hal ini bisa menjadi masukan untuk mekanisme di Indonesia agar lebih fokus terhadap mekanisme hukum tanpa mekanisme politis di MPR.

Kata Kunci: sistem semi presidensial, impeachment.

\section{Pokok Muatan}

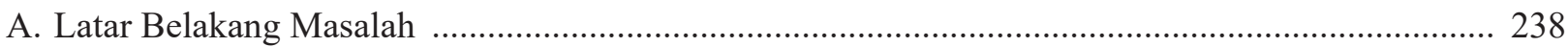

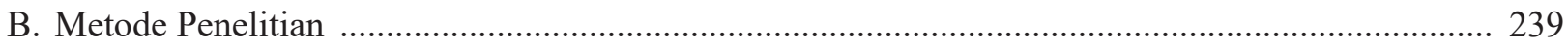

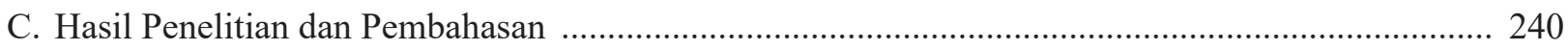

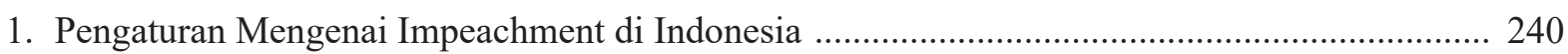

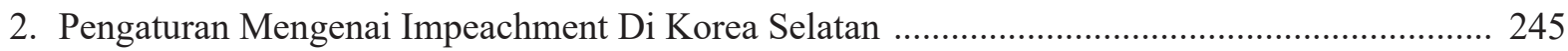

3. Keterkaitan Mekanisme Impeachment di Korea Selatan dengan Sistem Semi Presidensial ...... 248

4. Analisis Perbandingan Mekanisme Impeachment di Indonesia dan Korea Selatan ................... 248

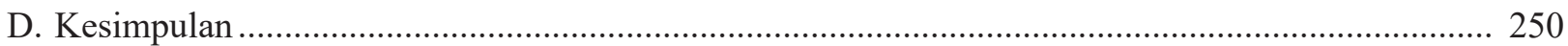

Artikel ini merupakan hasil dari penelitian yang didanai oleh Fakultas Hukum Universitas Indonesia melalui Hibah Riset Pemula Tahun 2018.

Alamat korespondensi: ryan.muthiara@gmail.com. 


\section{A. Latar Belakang Masalah}

Presiden merupakan organ yang penting dalam sebuah negara terutama yang menganut sistem presidensial. Keberadaan presiden dengan kekuasaan yang sangat besar dalam sistem presidensial menjadi syarat utama bagi negara tersebut. Selain itu, ciri sistem presidensial yang lain adalah masa jabatan presiden yang tetap (fixed term government) yang menyebabkan presiden tidak dapat dijatuhkan dalam masa jabatannya.

Sistem semi-presidensial berawal dari Republik Weimar Jerman (1919-1933), namun istilah "semi-presidensial" tidak digunakan sampai tahun 1958. Penggunaannya mulai populer pada akhir 1970-an, melalui karya Maurice Duverger, ketika Duverger menggunakannya untuk menggambarkan Republik Kelima Prancis. Ada beberapa negara di dunia dengan sistem pemerintahan semipresidensial, dengan beberapa bersandar lebih pada sistem presidensial murni yang memiliki presiden yang kuat namun beberapa negara lain memiliki presiden yang hampir seremonial dimana semua kekuatannya terletak pada perdana menteri. Perancis menawarkan pembagian kerja yang seimbang antara presiden dan perdana menteri. Meskipun tanggung jawab kedua pemimpin tidak secara eksplisit dinyatakan dalam konstitusi, lama kelamaan ia berkembang sebagai masalah kemanfaatan politik berdasarkan prinsip-prinsip konstitusional. ${ }^{1}$

Negara-negara yang memiliki sistem semi-presidensial telah meningkat dibandingkan masa lalu. Mayoritas bekas negara komunis juga mengadopsi sistem semi-presidensial, dengan sekitar 30\% masuk untuk sistem parlementer dan sekitar $10 \%$ mengadopsi sistem presidensiil. ${ }^{2}$ Sejumlah negara lain di Amerika Latin, Afrika, Asia, dan Eropa memiliki sistem semi-presidensial. Di masa lalu, beberapa negara demokrasi parlementer atau presidensial mengadopsi sistem semi-presidensial. Armenia misalkan meninggalkan sistem kepresidenan pada tahun 1994 untuk semipresidensial sementara Georgia juga melakukan hal yang sama di tahun $2004 .^{3}$

Terdapat sejumlah perbedaan antara sistem presidensial dengan sistem semi presidensial. Hal ini terlihat misalnya dalam sistem pemerintahan semi presidensial tidak terdapat kecendrungan presiden atau kepala negara untuk diktator karena adanya pembagian kewenangan antara kepala negara dengan kepala pemerintahan. Selain itu, presiden yang mempunyai legitimasi besar dimana pemilihannya langsung oleh rakyat hanya bertindak sebagai kepala negara (simbol) sementara pemerintahan dipimpin oleh perdana menteri yang dipilih oleh partai mayoritas di parlemen. Inilah yang membedakannya dengan sistem presidensial dimana presiden yang dipilih langsung oleh rakyat mempunyai kewenangan yang besar sebagai kepala negara sekaligus kepala pemerintahan. Sehingga, sekilas tidak terlihat adanya kemungkinan pemberhentian presiden dalam sistem semi presidensial.

Salah satu negara yang menggunakan sistem semi presidensial adalah Korea Selatan. Konstitusi Korea Selatan mengatur di Article 86 mengenai pemilihan Presiden melalui pemilihan umum sedangkan Perdana Menteri dipilih oleh Presiden. ${ }^{4}$ Selain itu, perdana menteri selaku pemegang kekuasaan pemerintahan bertanggungjawab kepada Presiden dan parlemen sehingga sistem pemerintahan pada Korea Selatan ini berdasarkan ciri yang dikemukakan oleh Shugart dan Carey adalah president parliamentary. ${ }^{5}$ Dengan ciri adanya presiden yang dipilih melalui pemilihan umum tersebut, maka Korea Selatan mempunyai kemiripan dengan Indonesia karena Presiden Indonesia dipilih melalui pemilihan umum.

\footnotetext{
Benjamin Elissa, Countries that have both A President and Prime Minister, http://www.worldatlas.com/articles/countries-that-have-both-apresident-and-a-prime-minister.html, diakses 4 Mei 2017.

Robert Elgie, et al., 2016, Semi-Presidentialism in The Caucasus And Central Asia, Macmillan Publishers, London, hlm. 23-25.

Ibid.

Article 86 Constitution of South Korea.

Fitra Arsil, 2017, Teori Sistem Pemerintahan, Pergeseran Konsep dan Saling Kontribusi Antar Sistem Pemerintahan di Berbagai Negara, Djokosoetono Research Center, Depok, hlm. 99.
} 
Negara yang menggunakan sistem pemerintahan presidensial memiliki perbedaan mekanisme pemberhentian presidennya, apalagi berbeda sistem pemerintahannya. Korea Selatan dengan Indonesia mempunyai mekanisme impeachment yang berbeda. Sebagaimana negara dengan sistem presidensial, presiden hanya dapat dijatuhkan dengan mekanisme tersendiri yang pada umumnya melalui proses yang tidak mudah. Hal ini mengingat masa jabatan seorang presiden yang tetap sehingga tidak dapat serta merta dijatuhkan oleh parlemen seperti yang terjadi di negara dengan sistem parlementer. Korea Selatan sendiri sudah pernah melakukan impeachment terhadap presidennya pada tahun 2004. Namun, pada masa itu, presiden Roh Muu Yun yang ingin diberhentikan tersebut tidak berhasil diberhentikan sehingga ia kembali menjabat sebagai presiden. Pada tahun 2016, terjadi lagi impeachment terhadap presiden Korea Park Geun Hye yang diduga melakukan tindakan kolusi yang merupakan alasan untuk diberhentikan seorang kepala negara. Hal ini terdapat dalam Konstitusi Korea Selatan pada Article 65 dan Chapter IV The Excecutive yang mengatur mengenai mekanisme dan alasan impeachment pejabat negara. ${ }^{6}$ Mekanisme impeachment di Korea Selatan terlihat lebih kepada mekanisme hukum karena proses akhir penetapan putusan berhentinya presidennya ada di Mahkamah Konstitusi.

Konteks Indonesia, pemberhentian presiden diatur di dalam Pasal 7A dan 7B yang melibatkan DPR, MK dan MPR. ${ }^{7}$ DPR mengajukan usulan pemberhentian presiden kepada MK yang kemudian akan ditindaklanjuti MK dengan putusan bahwa presiden bersalah atau tidak. Setelah itu, MK akan mengembalikan kepada DPR putusan tersebut dan akan diserahkan kepada MPR untuk diputuskan bahwa Presiden berhenti atau tidak. Proses tersebut terlihat mempunyai duamekanisme yaitu mekanisme hukum dan politik. Mekanisme hukum sudah seharusnya ditempuh untuk memperoleh kepastian hukum dan keadilan. Sementara mekanisme politik harus diteliti lagi apakah dibutuhkan atau tidak dalam mekanisme impeachment di Indonesia.

Oleh sebab itu, penting dan menarik untuk mengkaji mengenai mekanisme impeachment di negara dengan sistem pemerintahan semi presidensial yang salah satunya adalah Negara Korea Selatan dimana presiden dipilih melalui pemilihan umum yang biasanya hanya ada di negara dengan sistem presidensial seperti Indonesia. Hal ini untuk melihat hal-hal positif yang bisa dipraktikkan di Indonesia mengingat Indonesia juga memiliki mekanisme impeachment. Meskipun memiliki sistem pemerintahan yang berbeda dengan Indonesia, namun ada satu persamaan yang dapat ditarik dari mekanisme impeachment di Korea Selatan yaitu persamaan dalam hal lembaga yang terlibat dari proses impeachment yaitu lembaga legislatif dan lembaga yudisial. ${ }^{8}$ Berdasarkan uraian latar belakang diatas terdapat beberapa rumusan masalah yaitu: Pertama, Bagaimana pengaturan mengenai impeachment di Indonesia? Kedua, Bagaimana pengaturan mengenai impeachment di Korea Selatan? Ketiga, Bagaimana mekanisme impeachment di Korea Selatan dikaitkan dengan sistem semi pemerintahan yang digunakannya? Keempat, Bagaimana analisis perbandingan mekanisme impeachment di Indonesia dan Korea Selatan?

\section{B. Metode Penelitian}

Metode penelitian riset ini adalah yuridis normatif dengan menganalisis ketentuan mengenai

\footnotetext{
Constitusion of the Republic of Korea, http:/www.ilo.org/wcmsp5/groups/public/@ed_protect/@protrav/@ilo_aids/documents/ legaldocument/wcms 117333.pdf, diakses 4 Mei 2017.

Lihat Undang-Undang Dasar Negara Republik Indonesia Tahun 1945 Perubahan Keempat.

Jika dibandingkan dengan mekanisme impeachment di Amerika Serikat yang merupakan negara dengan sistem pemerintahan presidensial terlihat perbedaan dimana di AS mekanisme impeachment hanya melibatkan kekuasaan yudisial hanya sebagai pemimpin sidang pemutusan saja sementara juri dalam sidang tersebut adalah anggota Senat yang akan memutuskan apakah Presiden berhenti atau tidak. Lihat Robert Longley, "The Impeachment Process in US Government",https://www.thoughtco.com/impeachment-the-unthinkable-process-3322171, diakses 17 Juli 2019
} 
mekanisme impeachment di Negara Korea Selatan dan Indonesia, peraturan Mahkamah Konstitusi Korea Selatan dan Indonesia serta peraturan nasional lain yang terkait. Negara Korea Selatan dipilih karena menggunakan sistem presidensial awalnya yang sama dengan Indonesia namun berubah menjadi sistem semi presidensial. Hal ini dimaksudkan untuk mencari perbedaan atau pengaruh dari sistem pemerintahan yang digunakan dengan mekanisme impeachment di negara tersebut.

Jenis riset ini adalah qualitative research yang mengutamakan data sekunder yaitu berupa peraturan perundang-undangan serta literatur lain yang membahas mengenai mekanisme impeachment di Indonesia dan Korea. Selain dokumen tertulis, data juga didapatkan dengan wawancara dengan para narasumber relevan seperti Hakim Mahkamah Konstitusi, serta peneliti dan akademisi yang fokus terhadap kajian impeachment dan sistem pemerintahan. Pendekatan penelitian yang digunakan adalah comparative approach, historical approach dan statute approach. Comparative approach dilakukan dengan membandingkan pengaturan dan praktik proses impeachment di Indonesia sebelum dan sesudah perubahan UndangUndang Dasar Negara Republik Indonesia Tahun 1945 (UUD NRI Tahun 1945) serta perbandingan dengan negara lain yaitu Korea Selatan. Penulis melakukan pendekatan perbandingan sebagai cara yang menurut penulis dapat menghasilkan simpulan yang baik terkait dengan mekanisme impeachment di sebuah negara.

Perbandingan dilakukan dengan negara Korea Selatan karena menggunakan mekanisme yang juga melalui lembaga yang sama yaitu Mahkamah Konstitusi dan sudah pernah melakukan proses impeachment melalui MK pada tahun 2016 lalu. Historical approach digunakan agar dapat melihat bagaimana perjalanan sebuah negara terutama Indonesia dalam menemukan mekanisme yang tepat untuk proses pemberhentian pemimpin kekuasaan eksekutifnya. Sedangkan statute approach digunakan sebagai landasan hukum yang otentik mengenai penggunaan sebuah sistem pemerintahan dan mekanisme impeachment baik di Indonesia maupun di Korea Selatan, khususnya konstitusi masing-masing negara.

\section{Hasil Penelitian dan Pembahasan \\ 1. Pengaturan Mengenai Impeachment di Indonesia}

a. Sistem Pemerintahan di Indonesia

Teori sistem pemerintahan yang dikembangkan para ahli terdapat sistem semi presidensial yang memadukan ciri antara sistem presidensial dengan sistem parlementern. Robert Elgie mengemukakan terdapat dua bentuk dari sistem semi presidensial yaitu sistem president parliamentarism dan premier-parliamentary. ${ }^{9}$ Secara umum, perbedaan dari sistem presidensial dan parlementer terletak pada keterkaitan dan keterpisahan antara lembaga legislatif dan lembaga eksekutif. Dalam sistem presidensial, pemilihan presiden dan legislatif dilakukan secara terpisah, sehingga sumber legitimasi keduanya terpisah. Sementara dalam sistem parlementer, sumber legitimasi dari eksekutif adalah legislatif dimana pemerintahan yang terbentuk bisa jadi bukanlah dari partai pemenang pemilihan umum terutama dalam kondisi partai pemenang pemilihan umum tidak mayoritas. Hal ini menyebabkan diharuskannya koalisi antara beberapa partai sehingga sumber legitimasi dari eksekutif bergantung kepada lembaga legislatifnya.Sistem presidensial yang digunakan di Amerika Serikat (AS) dianggap sebagai contoh penerapan sistem presidensial yang murni.

Hal ini disebabkan kriteria utama dari

Robert Elgie, 2011, Semi Presidentialim: Sub Types and Democratic Performance, Oxford University Press, New York, hlm. 147-152. Bogdan Dima dalam artikelnya menemukanbahwa terdapat 7 (tujuh) negara yang memilih tipe pemerintahan premier parliament semi presidentialism dalam negara yang tergolong komunis yang sedang ditelitinya. Negara-negara yang dianggap memulai penggunaan sistem semi presidensial yaitu Kroasia, Bulgaria, Polandia, Romania dan Slovenia. Lihat Bogdan Dima, Impeachment Procecures against Presidents in Central and South East European Democracies: A Comparative Constitutional Approach. hlm. 3. 
sistem presidensial digunakan di AS yaitu pemilihan presiden langsung oleh rakyat dan masa jabatan pemerintahan yang memiliki waktu yang tetap. ${ }^{10}$ Dua kriteria utama tersebut, menurut Fitra Arsil berkaitan dengan sumber legitimasi dari kekuasaan eksekutif. Pemilihan langsung presiden misalkan menunjukkan bahwa sumber kekuasaan eksekutif tidak berasal dari kekuasaan legislatif. Sementara masa jabatan yang ditetap menunjukkan bahwa dalam sistem presidensial, eksekutif diganti hanya melalui pemilihan umum. Kedua hal ini menjadikan keduanya tidak mengganggu legitimasi yang lain. ${ }^{11}$

Soehino juga mengemukakan hal yang sama, bahwa sistem presidensial disebut sebagai sistem yang paling konsekuen untuk menerapkan trias politica Montesquieu. Hal ini disebabkan karena dalam sistem ini pemisahan kekuasaan Negara serta badan-badan yang memegang pelaksanaan masing-masing kekuasaan Negara dilakukan secara sempurna. Bahkan antara kekuasaan eksekutif dan legislative tidak ada hubungan pertanggungjawaban. Eksekutif dan legislatf masing-masing bertanggungjawab secara langsung kepada rakyat. ${ }^{12}$ Ada sedikitnya 9 (sembilan) prinsip pokok yang perlu dipenuhi oleh suatu sistem pemerintahan agar bisa dikategorikan sebagai sistem presidensial sekaligus membedakannya dengan sistem parlementer.

Tabel 1. ${ }^{13}$

Perbandingan Prinsip-Prinsip Pokok Sistem Presidensial dan Sistem Parlementer

\begin{tabular}{lll}
\hline No & \multicolumn{1}{c}{ Prinsip-prinsip sistem presidensial } & Prinsip-prinsip sistem parlementer \\
\hline 1 & $\begin{array}{l}\text { Terdapat pemisahan kekuasaan yang jelas antara } \\
\text { eksekutif, legislatif dan yudikatif }\end{array}$ & Eksekutif dan legislatif tidak terpisah \\
\hline 2 & $\begin{array}{l}\text { Presiden adalah eksekutif tunggal, kekuasaannya } \\
\text { tidak terbagi }\end{array}$ & $\begin{array}{l}\text { Eksekutif terpisah antara kepala pemerintahan } \\
\text { dan kepala negara }\end{array}$ \\
\hline 3 & Kepala pemerintahan sekaligus kepala negara & $\begin{array}{l}\text { Kepala pemerintahan diangkat oleh kepala } \\
\text { negara }\end{array}$ \\
\hline 4 & $\begin{array}{l}\text { Presiiden mengangkat para menteri sebagai } \\
\text { pembantu yang bertanggungjawab kepadanya }\end{array}$ & $\begin{array}{l}\text { Kepala pemerintahan mengangkat para menteri } \\
\text { sebagai suatu kesatuan institusi yang bersifat } \\
\text { kolektif }\end{array}$ \\
\hline 5 & $\begin{array}{l}\text { Anggota parlemen tidak boleh merangkap } \\
\text { jabatan menteri, begitu juga sebaliknya }\end{array}$ & $\begin{array}{l}\text { Menteri bisa merangkap menjadi anggota } \\
\text { parlemen }\end{array}$ \\
\hline 6 & $\begin{array}{l}\text { Presiden tidak bertanggungjawab keapda } \\
\text { parlemen dan tidak dapat membubarkannya }\end{array}$ & Pemerintah bertanggungjawab kepada parlemen \\
\hline 7 & Berlaku prinsip supremasi konstitusi & Berlaku prinsip supremasi parlemen \\
\hline 8 & Presiden bertanggungjawab kepada rakyat & $\begin{array}{l}\text { Sebagai konsekuensi supremasi parlemen maka } \\
\text { kedudukan parlemen lebih tinggi dari bagian- } \\
\text { bagian pemerintahan lainnya }\end{array}$ \\
\hline & & Kekuasaan negara terpusat kepada parlemen \\
\hline 9 & $\begin{array}{l}\text { Sebagai konsekuensi pemisahan kekuasaan } \\
\text { negara tersebar ke cabang pemerintahan lainnya }\end{array}$ \\
\hline
\end{tabular}

Sumber: Diolah oleh Penulis, 2019

10 Meskipun demikian, Amerika Serikat pernah mengalami masa dimana Presiden dipilih oleh House of Representative yakni pada pemilihan presiden tahun 1824 (yang sekaligus menjadi yang kedua dan yang terakhir menggunakan mekanisme pemilihan presiden melalui House of Representative). Lihat Skau, George H., "A Critical Analysis of the Presidential Election System”, Presidential Studies Quarterly, Vol.6, No. 4., 1976, hlm. 42-48.

$1 \quad$ Ibid., hlm. 69.

12 Soehino, 1993, Hukum Tata Negara: Sistem Pemerintahan Negara, Penerbit Liberty, 1993, hlm. 81.

13 Diolah dari Verney dalam Arend Lijphart (1995: hlm. 35-50); Ashshiddiqie (2007: hlm. 315-36); dan Budiarjo (2008: hlm. 295-360) sebagaimana dikutip oleh Syamsudin Haris, 2014, Partai, Pemilu, dan Parlemen Era Reformasi, Pustaka Obor. Jakarta, hlm. 9. 
UUD 1945 sebelum perubahan mengatur mengenai sistem pemerintahan yang menurut RM A.B. Kusuma menjadi kunci pokok pemerintahan di Indonesia yang diantaranyayaitu: ${ }^{14}$ Pertama, Presiden adalah penyelenggara pemerintah Negara yang tertinggi dibawah majelis. Oleh karena itu, pemerintahan Negara dipimpin oleh Presiden.

Kedua, Presiden tidak bertanggungjawab kepada DPR. Namun dalam hal persetujuan rancangan undang-undang, Presiden harus menjalankannya bersama dengan DPR. Indonesia sudah menggunakan sistem pemerintahan presidensial sebelum adanya perubahan UUD 1945. Bahkan sistem ini disepakati untuk tidak diubah sebagaimana disampaikan oleh Amin Aryoso sebagai pimpinan rapat dalam Rapat Panitia Adhoc III Badan Pekerja MPR pada tanggal 12 Oktober 1999. ${ }^{15}$

Berikut beberapa hal yang menjadi kesepakatan Panitia Ad Hoc dalam melakukan pembahasanrancanganPerubahanUUD 1945, yaitu: ${ }^{16}$ Pertama,pengubahan dilakukan dengan teknik amandemen, sehingga diktum lama yang diubah tetap menjadi bagian dalam naskah UUD 1945 dan diktum baru disisipkan pada dokumen UUD 1945, dengan demikian diktum asli yang telah diubah tetap dapat ditemukan dalam dokumen UUD 1945 yang telah diubah. Kedua, pembukaan yang berisi Pancasila sebagai dasar negara tidak dapat diubah. Ketiga, sistem pemerintahan presidensial dan bentuk negara kesatuan Republik Indonesia tidak menjadi objek amandemen. Keempat, materi penjelasan yang berkualifikasi sebagai norma hukum diangkan menjadi diktum pada bagian batang tubuh. Kelima, jika dalam pembahasan tidak tercapai kesepakatan terhadap rancangan diktum maka dikembalikan pada diktum naskah UUD 1945.

Meskipun UUD 1945 yang asli (sebelum amandemen) dipandang menganut sistem presidensial, namun beberapa ahli juga menyatakan bahwa sistem presidensial yang dibangun bukanlah yang murni. Hal ini terutama jika dilihat dari ciri-cirinya. Misalkan dalam hal pembuatan undangundang dilakukan bersama presiden dan DPR sedangkan dalam sistem presidensial Amerika Serikat, undang-undang dibuat oleh kongres, presiden hanya mempunyai hak veto sehingga tidak secara langsung mempengaruhi proses pembentukan undangundang. ${ }^{17}$

b. Pengaturan Impeachment di Indonesia Proses impeachment presiden Indonesia pada masa sebelum perubahan UUD 1945 sangat bergantung kepada kesepakatan dan aturan yang dibuat oleh Majelis Permusyawaratan Rakyat (MPR). Hal ini dikarenakan MPR merupakan lembaga yang memiliki kedudukan tertinggi dalam susunan ketatanegaraan Republik Indonesia dan dianggap sebagai pelaksana dari kedaulatan rakyat. ${ }^{18}$ Oleh karena itu, Presiden bertanggungjawab kepada MPR sebagai lembaga tertinggi negara dalam bentuk pertanggungjawaban politis dengan sanksi berupa pelepasan jabatan Presiden. Hal ini sesuai dengan aturan Pasal 4 Ketetapan Majelis Permusyawaratan Rakyat Nomor III/MPR/1978 tentang Kedudukan

14 RM A.B. Kusuma, 2011, Sistem Pemerintahan "Pendiri Negara” Versus Sistem Presidensial "Orde Reformasi”, Badan Penerbit Fakultas Hukum Universitas Indonesia, Depok, hlm. 14-15.

15 Sekretariat Jenderal Majelis Permusyawaratan Rakyat Republik Indonesia, 1999, Buku Kedua Jilid 6 Risalah Rapat Badab Pekerja Ad Hoc III Sidang Umum MPR RI, Sekretariat Jenderal Majelis Permusyawaratan Rakyat Republik Indonesia, Jakarta, hlm. $336-337$.

16 Sri Soemantri Martosoewignjo, 2016, Konstitusi Indonesia: Prosedur dan Sistem Perubahannya Sebelum dan Sesudah UUD 1945 Perubahan, Rosdakarya, Bandung, hlm. 202.

RM A.B. Kusuma, Op.cit., hlm. 17

18 Jimly Asshiddiqie, 2005, Format Kelembagaan Negara dan Pergeseran Kekuasaan dalam UUD 1945, FH UII Press, Yogyakarta, hlm. 11. 
dan Hubungan Tata Kerja Lembaga Tertinggi dengan/atau antara Lembaga-Lembaga Tinggi Negara (TAP MPR No III/MPR/1978) yang menjelaskan alasan pemberhentian presiden sebagai berikut: 1) Atas permintaan sendiri; 2)Berhalangan tetap; 3) Sungguhsungguh melanggar Haluan Negara.

Pengaturan mengenai pemberhentian Presiden tidak diatur secara tegas di dalam Batang Tubuh UUD 1945 sebelum perubahan sehingga pemberhentian presiden hanya mengacu kepada TAP MPR tersebut. Selain dalam Pasal 4, Pasal 7 ayat 2 TAP MPR yang sama mengatur mengenai pengawasan DPR dengan menyampaikan memorandum untuk mengingatkan Presiden jika DPR menganggap
Presiden telah melanggar haluan negara. Dalam hal Presiden tidak memperhatikan memorandum tersebut dalam 3 bulan, DPR dapat mengajukan memorandum yang kedua. Jika dalam 1 bulan memorandum yang kedua juga tidak diperhatikan oleh Presiden, maka DPR dapat meminta MPR mengadakan Sidang Istimewa untuk meminta pertanggungjawaban Presiden. Jika mengacu pada kosntitusi yang pernah digunakan, maka terlihat bahwa tidak ada pengaturan mengenai mekanisme impeachment yang secara tegas di dalam konstitusi baik UUD 1945, Konstitusi RIS, maupun UUDS 1950. Hal ini dapat digambarkan sebagai berikut:

Tabel 2.

Perbandingan Pengaturan Impeachment pada Setiap Konstitusi di Indonesia

\begin{tabular}{|c|c|c|c|c|}
\hline Konstitusi & UUD 1945 & Konstitusi RIS & UUDS 1950 & $\begin{array}{l}\text { UUD } 1945 \\
\text { perubahan }\end{array}$ \\
\hline $\begin{array}{l}\text { Pengaturan } \\
\text { Impeachment }\end{array}$ & Tidak ada & Tidak ada & Tidak ada & $\begin{array}{l}\text { Pasal 7A: } \\
\text { Presiden dan/atau } \\
\text { Wakil Presiden } \\
\text { dapatdiberhenti- } \\
\text { kan dalam masa } \\
\text { jabatannya oleh } \\
\text { MPR atas usul } \\
\text { DPR. }\end{array}$ \\
\hline $\begin{array}{l}\text { Pengaturan } \\
\text { Pergantian } \\
\text { Presiden }\end{array}$ & $\begin{array}{l}\text { Pasal 8: } \\
\text { Presiden harus } \\
\text { diganti oleh Wakil } \\
\text { Presiden sampai } \\
\text { habis waktunya } \\
\text { apabila ia mangkat, } \\
\text { berhenti atau tidak } \\
\text { dapat melakukan } \\
\text { kewajibannya } \\
\text { dalam masa } \\
\text { jabatannya. }\end{array}$ & $\begin{array}{l}\text { Pasal 72: } \\
\text { UU Federal } \\
\text { mengatur } \\
\text { pemilihan Presiden } \\
\text { yag baru untuk hal } \\
\text { apabila Presiden } \\
\text { tetap berhalangan, } \\
\text { berpulang atau } \\
\text { meletakkan } \\
\text { jabatannya. }\end{array}$ & $\begin{array}{l}\text { Pasal 48: } \\
\text { Penggantian Presiden } \\
\text { dilakukan dalam hal } \\
\text { Presiden mangkat, } \\
\text { berhenti atau tidak } \\
\text { dapat menjalankan } \\
\text { kewajibannya dalam masa } \\
\text { jabatannya ia digantikan } \\
\text { oleh Wakil Presiden } \\
\text { sampai habis masa } \\
\text { jabatannya. }\end{array}$ & \\
\hline $\begin{array}{l}\text { Sistem } \\
\text { Pemerintahan }\end{array}$ & Presidensial & Parlementer & Semi Presidensial & \\
\hline
\end{tabular}

Sumber: Diolah oleh Penulis, 2019.

Mendasarkan pada perbandingan keempat konstitusi tersebut dapat disimpulkan bahwa terdapat perbedaan pengaturan mengenai pemberhentian presiden dimana di dalam UUD 1945 naskah asli memang tidak tertulis pengaturan mengenai pemberhentian 
presiden. Namun pemberhentian presiden pada masa sebelum perubahan UUD 1945 dapat dilakukan dengan Sidang Istimewa MPR dalam hal Presiden melakukan kejahatan, pengkhianatan terhadap negara, serta tidak mampu lagi menjalankan jabatannya. ${ }^{19}$ Hal ini dibuktikan dengan impeachment yang terjadi pada masa Soekarno yang diberhentikan dalam Sidang Istimewa Majelis Permuswaratan Rakyat Smentara (MPRS) melalui Ketetapan Majelis Permusyawaratan Rakyat Sementara Nomor XXXIII/MPRS/1967 tentang Pencabutan Kekuasan Pemerintahan Negara dari Presiden Sukarno dan pemberhentian Abdurrahman Wahid dalam Sidang Isimewa MPR melalui Ketetapan Majelis Permusyawaratan Rakyat Nomor II/MPR/2001 tentang Pertanggungjawaban Presiden Republik Indonesia K.H. Abdurrahman Wahid. ${ }^{20}$ Sementara, pengaturan secara tegas kewenangan MPR dalam memberhentikan Presiden diatur di dalam TAP MPR No III/ MPR/1978 yang mengatur bahwa MPR memiliki kekuasaan memberhentikan Presiden dari masa jabatannya, jika yang bersangkutan telah "sungguh-sungguh melanggar haluan negara". ${ }^{21}$

Pada masa setelah perubahan UUD 1945 , terlihat adanya penegasan mengenai sistem pemerintahan presidensial. Jabatan presiden dalam sebuah pemerintahan presidensial sangatlah penting dan menjadi penentu dari stabil atau tidaknya sebuah pemerintahan. Mekskipun demikian, presiden dalam sistem presidensial tetap dapat diberhentikan sebagai salah satu mekanisme dari proses check and balances dan pengawasan. Hal ini dikarenakan adanya kekhawatiran munculnya sosok presiden yang otoriter sehingga perlu adanya pengawasan dan mekanisme untuk memberhentikan sang presiden. Artinya, presideen tetap dapat diberhentikan dalam masa jabatannya meskipun masa jabatannya disebut tetap dalam UUD 1945. Oleh karena keistimewaaanya, maka perlu sebuah mekanisme yang istimewa pula untuk dapat melakukan pemberhentian seorang presiden.

Pada sejarah sistem pemerintahan yang pernah digunakan di Indonesia, tercatat beberapa kasus pemberhentian presiden di Indonesia. UUD 1945 sebelum amandemen tidak memuat aturan yang detail tentang mekanisme pemberhentian presiden, baik alasan pemberhentian maupun prosedurnya; Satu-satunya ketentuan dalam UUD 1945 sebelum perubahan, yang secara implisit mengatur kemungkinan pemberhentian presiden di tengah masa jabatannya adalah Pasal 8 UUD 1945 yang berbunyi: "Jika Presiden Mangkat, berhenti atau tidak dapat melakukan kewajibannya dalam masa jabatannya ia diganti oleh Wakil Presiden sampai habis masa jabatannya." Kemudian dalam Penjelasan UUD 1945 angka VII Alinea ketiga, dijelaskan:

"Jika Dewan Menganggap bahwa Presiden sungguh melanggar haluan negara yang telah ditetapkan oleh Undang-Undang Dasar atau oleh Majelis Permusyawaratan Rakyat, maka Majelis itu dapat diundang untuk persidangan istimewa agar supaya bisa meminta pertanggungan jawab Presiden." 22

Abdul Gani Abdullah, 2005, Laporan Akhir Tim Pengkajian Hukum tentang Impeachment dalam Sisten Hukum Tata Negara, BPHN, Jakarta, hlm. 30 .

Ibid., hlm. 3 .

21 Lihat Pasal 4 Ketetapan Majelis Permusyawaratan Rakyat Nomor III/MPR/1978 tentang Kedudukan dan Hubungan Tata Kerja Lembaga Tertinggi Negara Dengan/Atau Antar Lembaga-Lembaga Tinggi Negara.

22 Penjelasan Undang-Undang Dasar Tahun 1945 angka VII Alinea ketiga. 
Ketentuan lebih lanjut mengenai kewenangan MPR untuk memberhentikan Presiden diatur dalam Tap MPR RI No. VI/ MPR/1973 dan Tap MPR No. III/MPR 1978 yang menegaskan bahwa: Pertama, apabila DPR menganggap bahwa Presiden sungguhsungguh melanggar haluan negara maka DPR menyampaikan memorandum untuk mengingatkan Presiden. Kedua, apabila dalam waktu tiga bulan Presiden tidak memperhatikan memorandum tersebut, maka DPR menyampaikan memorandum kedua. Ketiga, apabila dalam waktu satu bulan memorandum kedua ini tidak diindahkan Presiden maka DPR dapat meminta MPR untuk mengadakan Sidang Istimewa untuk meminta pertanggungan jawab Presiden.

Setelah perubahan UUD 1945, pengaturan mengenai pemberhentian presiden disebut secara tegas dalam Pasal 7A dan 7B. Selain itu, juga diatur di dalam Pasal 10 ayat (3) Undang-Undang No. 24 Tahun 2003 Tentang Mahkamah Konstitusi memberikan penjelasan jenis-jenis pelanggaran hukum tersebut. ${ }^{23}$ Pasal 7B mengatur mengenai alur pemberhentian presiden yaitu dimulai dari usul pemberhentian Presiden dan/atau Wakil Presiden oleh Dewan Perwakilan Rakyat kepada Majelis Permusyawaratan Rakyat dengan terlebih dahulu mengajukan permintaan kepada Mahkamah Konstitusi untuk memeriksa, mengadili, dan memutus pendapat Dewan Perwakilan Rakyat terkait dugaan bahwa Presiden/Wakil Presiden telah melakukan pelanggaran hukum berupa pengkhianatan terhadap negara, korupsi, penyuapan, tindak pidana berat lainnya atau perbuatan tercela dan atau pendapat bahwa Presiden/Wakil Presiden tidak lagi memenuhi syarat sebagai Presiden dan atau Wakil Presiden. Setelah ditetapkan terbukti melakukan pelanggaran hukum, maka MPR akan bersidang untuk menetapkan apakah presiden tersebut diberhentikan atau tidak.

\section{Pengaturan Mengenai Impeachment Di Korea Selatan}

\section{a. Sistem Pemerintahan Korea Selatan}

Sistem semi presidensial di negaranegara di dunia terbagi atas dua jenis sebagaimana dikemukakan oleh Shugart dan Carey yaitu sistem president parliemantary dan sistem premier presidential. Terlebih dahulu harus dilihat ciri yang terdapat dalam pemerintahan Korea Selatan untuk dapat memasukkannya ke dalam salah satu sistem pemerintahan semi presidensial tersebut. Korea Selatan mempunyai seorang Presiden yang dipilih melalui pemilihan umum dan seorang Perdana Menteri yang dipilih oleh Presiden untuk memimpin kabinetnya. ${ }^{24}$ Konstitusi Korea Selatan mengatur mengenai kekuasaan eksekutif dalam Section 2 subsection 1 yang menyebutkan bahwa cabang kekuasaan eksekutif terdiri dari perdana menteri dan anggota State Council. Prime Minister dan State Council mempunyai relasi yang dituangkan dalam Article 87 sebagai berikut: ${ }^{25}$

The members of the State Council shall be appointed by the President on the recom-

\footnotetext{
23 Pasal 10 ayat (3) Undang-Undang Nomor 24 Tahun 2003 tentang Mahkamah Konstitusi, mengatur mengenai pelanggaran hukum sebagai alasan impeachment presiden sebagai berikut:

Penghianatan terhadap Negara adalah tindak pidana terhadap keamanan Negara sebagaimana diatur dalam undang-undang

Korupsi dan penyuapan adalah adalah tindak pidana korupsi atau penyuapan sebagaimana yang diatur dalam undang-undang

Tindak pidana berat lainnya adalah tindak pidana yang diancam dengan pidana 5 (lima) tahun atau lebih.

Perbuatan tercela adalah perbuatan yang dapat merendahkan martabat Presiden dan/atau wakil presiden

Tidak lagi memenuhi syarat sebagai Presiden dan/atau wakil Presiden adalah syarat sebagaimana yang ditentukan dalam Pasal 6 UndangUndang Dasar 1945.

24 Lihat Article 86 Constitution of South Korea

25 Lihat Article 87 Constitution of South Korea.
} 
mendation of the Prime Minister. The members of the State Council shall assist the President in the conduct of State affairs and, as constituents of the State Council, shall deliberate on State affairs.

The Prime Minister may recommend to the President the removal of a member of the State Council from office.

No member of the military shall be appointed a member of the State Council unless he is retired from active duty.

Perdana menteri dapat memberikan rekomendasi untuk keanggotaan dari State Council bahkan dapat mengajukan pemberhentian untuk State Council. Sementara State Council ini terdiri dari Perdana Menteri, Presiden, dan anggota lainnya yang tidak boleh lebih dari 30 dan tidak kurang dari 15 orang. Presiden dan Wakil Presiden secara tidak langsung menjadi ketua dan wakil ketua State Council. Dalam proses pemberhentian, yang dapat mengajukan proses impeachment Presiden adalah National Assembly dengan mekanisme yang tidak mudah sehingga dapat dikatakan Presiden tidak dapat dijatuhkan dalam masa jabatannya kecuali dengan alasan khusus yang menjadi ciri dari sistem presidensial. Namun, Korea Selatan mempunyai perdana menteri yang merupakan salah satu ciri dari sistem parlementer. Robert Elgie mengemukakan bahwa terdapat ciri khas dari negara yang menggunakan sistem semi presidensial yaitu adanya pemilihan presiden secara langsung oleh rakyat dan jabatan perdana menteri ada sebagai pemegang pemerintahan dan memimpin kabinet. ${ }^{26}$

Hal ini ada di negara Korea Selatan dimana terdapat seorang presiden dan seorang perdana menteri namun presiden dipilih langsung dan mempunyai masa jabatan yang tetap kecuali dengan pemberhentian dengan mekanisme impeachment. Meskipun masa jabatannya tetap, Presiden di Korea Selatan tidak dapat dipilih kembali sebagaimana yang biasanya terjadi di negara-negara dengan sistem pemerintahan lainnya. Selain itu, hal yang menarik dari adalah adanya pemilihan di National Assembly dalam hal calon presiden yang mengikuti pemilihan umum mendapatkan suara yang sama banyaknya. Calon terpilih adalah mereka yang dipilih oleh mayoritas suara di National Assembly.

Selain itu, hal menarik lainnya adalah adanya kekuatan yang besar dari Presiden sementara perdana manteri terbatas kekuasaannya, namun dalam hal tertentu terdapat kebijakan yang harus dengan pertimbangan perdana menteri seperti pemilihan kepala kementerian yang dipilih oleh presiden. Sementara dalam hal tanggungjawab, perdana menteri bertanggungjawab kepada Presiden dan kepada National Assembly sehingga sistem pemerintahannya adalah semi presidensial dengan bentuk president parliamentary. Article 63 Konstitusi Korea Selatan mengatur bahwa: ${ }^{27}$

The National Assembly may pass a recommendation for the removal of the Prime Minister or a State Council member from office.

A recommendation for removal as referred to in paragraph (1) may be introduced by one third

26 Ciri ini juga dikemukakan oleh Maurice Duverger mengenai ciri sistem semi presidensial yang menurutnya terdiri dari:

[a] political regime is considered as semi-presidential if the constitution which established it combines three elements: (1) the president of the republic is elected by universal suffrage; (2) he possesses quite considerable powers; (3) he has opposite him, however, a prime minister and ministers who possess executive and governmental power and can stay in office only if the parliament does not show its opposition to them. Lihat Robert Elgie, 2011, Semi Presidentialisme: Sub Types and Demoractice Performance, Oxford Universtity Press, New York, hlm. 20.

27 Lihat Article 87 Constitution of South Korea. 
or more of the total members of the National Assembly, and shall be passed with the concurrent vote of a majority of the total members of the National Assembly.

Sebagaimana pembagian bentuk sistem pemerintahan semi presidensial oleh Shugart dan Carey, perdana manteri di Korea Selatan selain bertanggungjawab kepada Presiden juga bertanggungjawab kepada National Assembly yang merupakan parlemen Korea Selatan. Bahkan, tidak hanya bertanggungjawab, National Assembly juga dapat mengajukan impeachment terhadap perdana menteri. Selain itu, dengan sistem pemerintahan semi presidensial ini membuat Korea menjadi negara yang multipartai karena di satu sisi memberikan ruang untuk partai politik berlomba-lomba dalam hal pemilihan presiden dan berlomba agar ditunjutk wakilnya sebagai perdana menteri.

Berdasarkan ciri-ciri yang terdapat dalam negara Korea Selatan diatas, dapat ditegaskan bahwa Korea Selatan menggunakan sistem semi presidensial dengan bentuk president parliamentary dimana presiden mempunyai kekuasaan yang besar yang terlihat dari pasal-pasal yang mengatur mengenai kekuasaan presiden sementara perdana menteri selain bertanggungjawab kepada parlemen juga bertanggungjawab kepada presiden. ${ }^{28}$

c. Pengaturan Impeachment di Korea
Selatan
Presiden di Negara Korea Selatan
mempunyai kekuasaan yang hampir
sama dengan Presiden di negara dengan
sistem presidensial. Meskipun sejumlah

ahli mengatakan bahwa Korea Selatan menggunakan sistem presidensial, namun ada sejumlah hal yang menjadikannya masih diperdebatkan oleh sejumlah ahli salah satunya adalah adanya perdana menteri. Article 86 mengatur bahwa perdana menteri dipilih oleh Presiden dan akan menjadi pemimpin dari kabinet. Padahal, Perdana menteri dalam sebuah negara pada umumnya mencirikan penggunaan sistem pemerintahan parlementer. Bahkan, perdana menteri di Korea Selatan bertanggungjawab kepada Presiden.

Dalam sistem semi presidensial Korea Selatan terdapat seorang Presiden yang dipilih langsung oleh rakyat dengan masa jabatan tertentu. Masa jabatan Presiden diatur di dalam Article 70 Konstitusi Korea Selatan yang mengatur bahwa Presiden memiliki masa jabatan 5 tahun dengan tidak boleh dipilih kembali. Artinya, Presiden sesungguhnya tidak dapat dijatuhkan dalam masa jabatannya sehingga harus ada mekanisme untuk membatasi kekuasaan presiden selama 5 tahun tersebut yaitu dengan mekanisme impeachment. Hal ini biasanya terjadi di negara dengan sistem semi presidensial yang membatasi jabatan presiden dan parlemen tidak dapat menjatuhkan presiden (ciri yang hanya terdapat dalam sistem parlementer).

Proses impeachment di Korea Selatan diatur di dalam Konstitusinya dalam beberapa pasal. Lembaga yang terlibat dalam proses impeachment adalah Mahkamah Konstitusi dan National Assembly. Pasal 111 Konstitusi Korea Selatan diatur mengenai kewenangan Mahkamah Konstitusi negara tersebut yaitu untuk memutus perkara yang salah satunya berkenaan dengan perkara

\footnotetext{
Sistem semi presidensial seperti ini juga diterapkan di Timor Leste dimana menggabungkan dua kekuatan yaitu presiden dan pemerintahan (perdana menteri) dalam satu kesatuan. Hal ini mengakibatkan presiden dan perdana menteri dapat mengklaim bahwa masing-masing mendapatkan mandat langsung dari rakyat. Namun, sayangnya dua kekuatan besar ini mengakibatkan ketidakstabilan dalam pemerintahan Timor Leste. Hal ini terjadi pada masa pemerintahan Xanana Gusmao yang menjadi presiden dengan dipilih langsung oleh rakyat dan perdana menteri Dr. Maro Alkatiri, yang memenangkan 55 kursi dan 88 kursi di Constitutional Assembly. Lihat Dennis Shoesmith, "Timor Leste: Divided Leadership in a Semi-Presidential System”, Asian Survey, Vol. 43, No.2, March-April 2003, hlm. $231-252$.
} 
permintaan pertanggungjawaban Presiden (impeachment). ${ }^{29}$

Adapun mengenai impeachment diatur di dalam Article 63 Konstitusi Korea Selatan yaitu objek dari impeachment adalah Presiden, Perdana Menteri, anggota Dewan Negara, kepala Kementerian Eksekutif, Hakim Konstitusi, hakim, anggota Komisi Pemilihan Umum, Ketua dan anggota Dewan Audit dan Inspeksi, dan publik lainnya Pejabat yang ditunjuk oleh UndangUndang serta mengatur mengenai proses impeachmentnya. ${ }^{30}$ Sementara alasan dapat dilakukannya impeachment hanya disebutkan dalam hal melanggar undang-undang. Artinya tidak ada pengaturan secara spesifik mengenai alasan impeachment sebagaimana di dalam UUD 1945 NRI.

\section{Keterkaitan Mekanisme Impeachment di Korea Selatan dengan Sistem Semi Presidensial}

Pengaturan mengenai mekanisme di Korea Selatan terdapat dalam konstitusinya khususnya dalam pasal mengenai Mahkamah Konstitusi Korea Selatan. Pasal 111 Konstitusi Korea Selatan mengatur mengenai kewenangan MK nya untuk melakukan proses impeachment dan bahkan menjadi penentu akhir dari berhentinya seorang presiden atau tidak. Hal ini salah satunya terlihat dari putusan hakim MK Korea Selatan pada proses impeachment Roh Moo-Hyun pada tahun 2004 yang menolak untuk memberhentikan Roh Moo-Hyun dari jabatannya sebagai Presiden Korea Selatan. ${ }^{31}$

Proses impeachment di Korea Selatan hanya melibatkan National Assembly dan Constitutional Court dimana National Assembly akan langsung mengajukan pemberhentian Presiden kepada Constitutional Court dan akan langsung diputuskan berhenti atau tidaknya oleh Constitutional Court sendiri. ${ }^{32}$ Hal ini mempunyai kaitan dengan sistem semi presidensial yang digunakan. Pada negara dengan sistem semi presidensial, kekuasaan terbagi kepada Presiden dan Perdana Menteri sehingga terkadang terdapat konflik antara keduanya. Misalkan di Negara Polandia pada 1991-1995 terjadi konflik internal antara Presiden dan Perdana Menterinya. ${ }^{33}$ Selain itu, khususnya dalam hal pemberhentian (dismissal) Presiden atau Perdana Menteri khususnya Perdana Menteri terdapat dua opsi yang bisa dilakukan yaitu: 1). Presiden dan legislatif memberhentikan Perdana Menteri, 2). Legislatif memberhentikan Perdana Menteri. ${ }^{34}$

Kedua opsi tersebut memperlihatkan bahwa pemberhentian Perdana Menteri pada sistem semi presidensial memang lebih banyak diambil alih oleh legislatif karena Presiden hanya bertindak sebagai kepala negara (simbol) saja sehingga ada negara yang tidak memberikan kekuasaan kepada Presiden untuk memberhentikan perdana menteri. Hal ini berpengaruh terhadap pemberhentian Presiden dimana setelah adanya MK, Presiden hanya dapat diberhentikan oleh MK dengan alasan Presiden tidak dapat diganggu-gugat oleh Perdana Menteri (untuk menstabilkan pemerintahan).

\section{Analisis Perbandingan Mekanisme Im- peachment di Indonesia dan Korea Selatan}

Terdapat dua hal yang menjadi pembanding untuk mekanisme pemberhentian Presiden yaitu mekanisme dan alasan. Pertama, dilihat dari mekanismenya, impeachment di Indonesia dengan di Korea Selatan terdapat perbedaan yaitu proses impeachment di Indonesia hanya ditujukan kepada

\footnotetext{
Republic of South Korea, Constitution of South Korea, Article 111.

Republic of South Korea, Constitution of South Korea, Article 63.

Rusdianto, "Proses Impeachment dalam Konstitusi Negara-Negara Modern", Jurnal Hukum, Vol. XIX, No. 19, Oktober 2010, hlm. 113.

Young Jae Lee, "Law, Politics, and Impeachment: The Impeachment of Roh Moo-hyun from a Comparative Constitutional Perspectives", The American Journal of Comparative Law, Vol. 53, No. 2 (Spring, 2005), hlm. 403-432.

33 Thomas Sedelius, et al., "Two Decades of Semi-Presidentialism: Issue of Intra-Excecutive Conflict in Central and Eastern Europe 1991-2011," East European Politics Journal, Vol. 29, No.2, January 2013, hlm. 110.

34 Sujit Choudry, et al., 2018, Semi Presidentialism and Inclusive Governance in Ukraine: Reflection for Constitutional Reform, International
} IDEA, Sweden, hlm. 39. 
Presiden dan/atau Wakil Presiden sebagaimana dimaksud pada Pasal 7A dan 7B UUD 1945. DPR mengajukan usulan pemberhentian Presiden kepada Mahkamah Konstitusi dan Mahkamah Konstitusi memutuskan pendapat DPR bahwa Presiden telah melanggar hukum atau alasan konstitusional lainnya dalam waktu paling lama 90 hari. Setelah memutuskan pendapat DPR tersebut, maka

Mahkamah Konstitusi menyampaikan putusan itu kepada DPR apakah Presiden benarbenar telah melakukan pelanggaran sebagaimana yang dituduhkan oleh DPR. Dalam hal putusan Mahkamah Konstitusi tersebut menyatakan bahwa Presiden telah melanggar hukum sebagaimana dimaksud oleh DPR, maka DPR mengajukan putusan MK tersebut kepada MPR untuk dilaksanakan sidang istimewa dalam waktu paling lama 30 hari, dan diberikan kesempatan kepada Presiden untuk melakukan pembelaan terlebih dahulu. Dengan demikian peran Mahkamah Konstitusi dalam proses impeachment Presiden di Indonesia adalah sebagai penengah yang putusannya tidak bisa eksekutorial dalam arti bisa langsung memberhentikan Presiden. Hal ini dapat terlihat dari gambar berikut: ${ }^{35}$

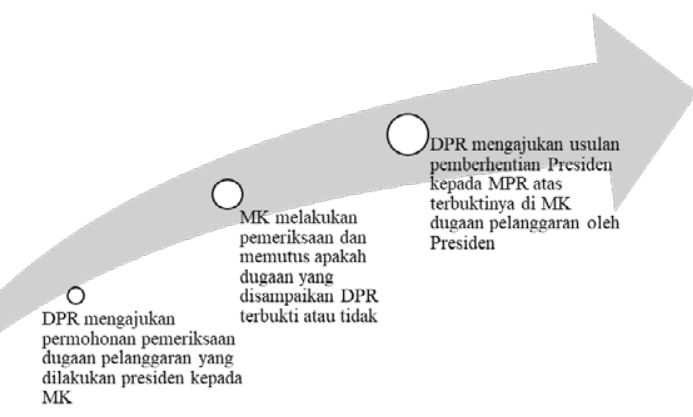

Gambar 1. Proses Impeachment Presiden di Indonesia

Sumber: Diolah oleh Penulis, 2019.

Sementara impeachment di Korea Selatan tidak hanay ditujukan kepada Presiden dan/atau Wakil Presiden tetapi juga terhadap Perdana Menteri, anggota State Council, Menteri, Hakim
Mahkamah Konstitusi, anggota Komisi Pemilihan Umum dan pejabat lainnya yang ditentukan dalam undang-undang. Mekanisme impeachment di Korea Selatan dimulai dengan usulan National Assembly kapada Constitutional Court untuk memberhentikan Presiden. Presiden dapat langsung diberhentikan oleh Constitutional Court tanpa harus dikembalikan kepada lembaga legislatifnya. Hal ini berkaitan dengan sistem kamar di Korea Selatan yang hanya menggunakan satu kamar (unicameral) yaitu National Assembly serta sistem pemerintahannya dimana Presiden dalam sistem semi presidensial hanya bertugas sebagai kepala negara sehingga lembaga legislatif tidak begitu memiliki kaitan yang erat dengan Presiden, justru berkaitan dengan pemerintahan yang dipimpin oleh perdana menteri. Hal ini membuat lembaga legislatif tidak mempunyai kekuatan yang besar untuk dapat memutuskan pemberhentian Presiden. Proses pemberhentian Presiden di Korea Selatan dapat dilihat sebagai berikut: ${ }^{36}$

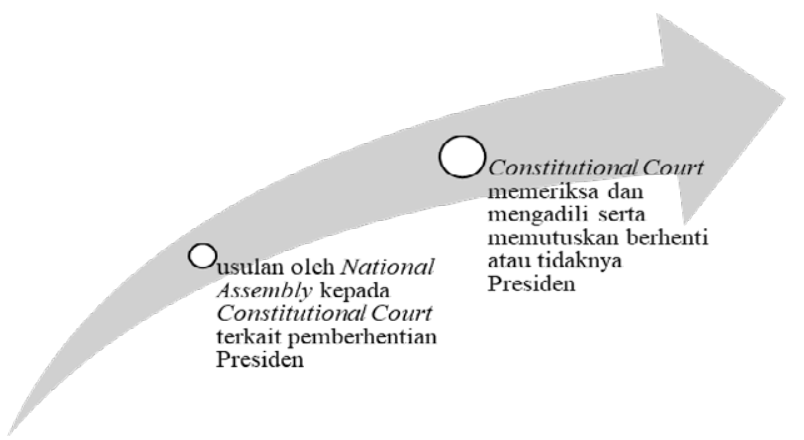

Gambar 2. Proses Impeachment Presiden di Korea Selatan

Sumber: Diolah oleh Penulis, 2019.

Kedua, dilihat dari segi alasan pemberhentian Presidennya terdapat perbedaan antara Indonesia dan Korea Selatan. Dalam konteks Indonesia, alasan pemberhentian Presiden dan atau Wakil Presiden diatur di dalam Pasal 7A dimana Presiden dapat diberhentikan dalam masa jabatannya jika

\footnotetext{
35 Lihat Pasal 7B Undang-Undang Dasar Tahun 1945.

36 Republic of South Korea, Constitution of South Korea, Article 65 dan 111.
} 
terbukti telah melakukan pelanggaran hukum berupa pengkhianatan terhadap negara, korupsi, penyuapan, tindak pidana berat lainnya, atau perbuatan tercela maupun apabila terbukti tidak lagi memenuhi syarat sebagai Presiden dan/atau Wakil Presiden. Sementara di Korea Selatan, alasan untuk pemberhentian Presiden hanya disebutkan karena pelanggaran konstitusi dan undang-undang. Dalam konstitusinya, tidak dijelaskan dengan detil alasan pemberhentian tersebut, hal ini berbeda dengan di Indonesia yang secara detil menjelaskan di dalam konstitusi mengenai alasan pemberhentian Presidennya.

\section{Kesimpulan}

Berdasarkan hal-hal yang diuraikan diatas terdapat beberapa kesimpulan, yaitu: Pertama, mekanisme impeachment di Indonesia sebelum perubahan UUD 1945 belum ada secara eksplisit disebutkan di dalam Konstitusi baik UUD 1945 naskah asli, Konstitusi RIS, maupun UUDS 1950. Namun, pengaturan mengenai impeachment ada di dalam TAP MPR Nomor III/MPR/1978 yang memberikan kewenangan kepada MPR untuk memberhentikan presiden. Pasca perubahan UUD 1945 kemudian diatur di dalam Pasal 7A dan Pasal 7B UUD 1945 mengenai proses impeachment yang melibatkan tiga lembaga yaitu DPR, MPR dan Mahkamah Konstitusi. dimana pemutus akhir dari diberhentikannya presiden di Indonesia yaitu di MPR. Itulah sebabnya para ahli banyak menyatakan bahwa proses impeachment di Indonesia lebih besar unsur politiknya dibandingkan unsur hukumnya. Kedua, mekanisme impeachment di Negara Korea Selatan diatur di dalam Pasal 63 dan Pasal 111 Konstitusi Korea Selatan yang memperlihatkan bahwa mekanisme impeachment dilakukan dengan melibatkan dua lembaga yaitu parlemen dan lembaga yudisial yaitu Mahkamah Konstitusi. Penentuan akhir dari diberhentikan atau tidaknya seorang presiden di Korea Selatan dilakukan di Mahkamah Konstitusi sehingga dianggap memenuhi proses hukum.

Ketiga, pengaturan mekanisme impeachment di Korea Selatan dapat dikaitkan dengan sistem semi presidensial yang digunakan. Hal ini dapat terlihat dari proses yang hanya melibatkan dua lembaga yaitu National Assembly dan Constitutional Court saja. Dalam sistem semi presidensial, parlemen tidak dapat menjatuhkan Presiden dalam masa jabatannya sehingga ada mekanisme lain yang menjadi tempat yang legal bagi parlemen (National Assembly) untuk memberhentikan Presiden dalam masa jabatannya yaitu melalui Constitutional Court yang digunakan di Korea Selatan. Keempat, dapat disimpulkan bahwa dalam hal pemberhentian presiden, baik pada sistem presidensial maupun sistem semi presidensial terdapat persamaan yaitu melibatkan lembaga yudisial yaitu Mahkamah Konstitusi terutama pada sistem semi presidensial di Korea Selatan dengan bentuk president parliamentarism.

\section{DAFTAR PUSTAKA}

\section{A. Buku}

Abdullah, Abdul Gani, 2005, Laporan Akhir Tim Pengkajian Hukum tentang Impeachment dalam Sistem Hukum Tata Negara, BPHN, Jakarta.

Arsil, Fitra, 2017, Teori Sistem Pemerintahan, Pergeseran Konsep dan Saling Kontribusi Antar Sistem Pemerintahan di Berbagai Negara, Djokosoetono Research Center, Depok.
Asshiddiqie, Jimly, 2005, Format Kelembagaan Negara dan Pergeseran Kekuasaan dalam UUD 1945, FH UII Press, Yogyakarta.

Choudry, Sujit, et al., 2018, Semi Presidentialism and Inclusive Governance in Ukraine: Reflection for Constitutional Reform, International IDEA, Sweden.

Elgie, Robert, 2011, Semi Presidentialism, Sub Types and Democratic Performace, Oxford Universtity Press, New York. 
Elgie, Robert, et al., 2016, Semi-Presidentialism in the Caucasus and Central Asia. Macmillan Publisher. London.

Haris, Syamsudin, 2014, Partai, Pemilu, dan Parlemen Era Reformasi, Pustaka Obor, Jakarta.

Kusuma, R.M. A.B., 2011, Sistem Pemerintahan "Pendiri Negara” Versus Sistem Presidensial "Orde Reformasi", Badan Penerbit Fakultas Hukum Universitas Indonesia, Depok.

Lijphart, Arend, 1999, Pattern of Democracy: Government Forms and Performance in Thirty-Six Countries, Yale University Press, New Haven.

Martosoewignjo, Sri Soemantri, 2016, Konstitusi Indonesia: Prosedur dan Sistem Perubahannya Sebelum dan Sesudah UUD 1945 Perubahan, Rosdakarya, Bandung.

Sekretariat Jenderal Majelis Permusyawaratan Rakyat Republik Indonesia, 1999, Buku Kedua Jilid 6 Risalah Rapat Badab Pekerja Ad Hoc III Sidang Umum MPR RI, Sekretariat Jenderal Majelis Permusyawaratan Rakyat Republik Indonesia, Jakarta.

Soehino, 1993, Hukum Tata Negara: Sistem Pemerintahan Negara, Penerbit Liberty, Yogyakarta.

\section{B. Artikel Jurnal}

Lee, Young Jae, "Law, Politics, and Impeachment: The Impeachment of Roh Moo-hyun from a Comparative Constitutional Perspectives", The American Journal of Comparative Law, Vol. 53, No. 2, 2005.

Rusdianto, "Proses Impeachment dalam Konstitusi Negara-Negara Modern". Jurnal Hukum, Vol. XIX, No. 19, Oktober 2010.

Sedelius, Thomas, et al., "Two Decades of SemiPresidentialism: Issue of Intra-Excecutive Conflict in Central and Eastern Europe 19912011”. East European Politics Journal, Vol.
29, No.2, January 2013.

Shoesmith, Dennis "Timor Leste: Divided Leadership in a Semi-Presidential System", Asian Survey, Vol. 43, No.2, March-April 2003.

Skau, George H., "A Critical Analysis of the Presidential Election Sistem”, Presidential Studies Quarterly, Vol. 6, No. 4., 1976.

\section{Internet}

Elissa, Benjamin, "Countries that have both A President and Prime Minister", http://www. worldatlas.com/articles/countries-that-haveboth-a-president-and-a-prime-minister.html, diakses 4 Mei 2019.

Constitusion of the Republic of Korea, http:// www.ilo.org/wcmsp5/groups/public/@ed_ protect/@protrav/@ilo_aids/documents/ legaldocument/wcms_117333.pdf, diakses 4 Mei 2019.

Longley, Robert, "The Impeachment Process in US Government", https://www.thoughtco. com/impeachment-the-unthinkableprocess-3322171, diakses 17 Juli 2019.

\section{Peraturan Perundang-Undangan}

Konstitusi Republik Indonesia Serikat Tahun 1949. Undang-Undang Dasar 1945 Pasca Perubahan Keempat.

Ketetapan Majelis Permusyawaratan Rakyat Nomor III/MPR/1978 tentang Kedudukan dan Hubungan Tata Kerja Lembaga Tertinggi Negara Dengan/Atau Antar LembagaLembaga Tinggi Negara.

Undang-Undang Nomor 24 Tahun 2003 tentang Mahkamah Konstitusi (Lembaran Negara Tahun 2003 Nomor 98, Tambahan Lembaran Negara Nomor 4316).

\section{E. Dokumen Lain}

Constitution of South Korea. 